[11] Zakharova, E. A. (2017). Metody obucheniya inostrannomu yaziku v istoricheskom kontekste i ikh znachimost' v sovremennoy praktike inoyazychnogo obrazovaniya. Nauka i shkola, 3, 174-183.

[12] Lukina, L. V. (2007). TSeli i metody obucheniya inostrannymyazykam v istoricheskom i lingvodidakticheskom kontekste. Nauchnyy vestnik Voronezhskogo gosudarstvennogo arkhitekturno-stroitel'nogo universiteta. Seriya «Lingvistika i mezhkul'turnaya kommunikatsiya», 2, 56-62.

[13] Kovaleva, E. A. (2013). Stanovlenie i razvitie inoyazychnogo obrazovaniya v otechestvennoy gimnazii XIX - nachala XX vv. Moscow, 22.

[14] Hoppenstedt, G., Frühes, W. B. (2011). Fremdsprachenlernen mit dem CLIL-Ansatz Einführung und Praxisbeispiele. Goethe-Institut. München, 22. Available at: https://www.goethe.de/resources/files/pdf96/2clil-fruehes-fremdsprachenlernen.pdf

[15] Sacara-Onita, A. (2014). Die Wichtigsten Methoden des Fremdsprachenunterrichts. Annals of Faculty of Economics, 1 (2), 131-134.

[16] Korol', S. V. (2012). Komunikativniy pidkhid u navchanni inozemnikhmov. Pedagogichniy diskurs, 11, 133-136.

\title{
THE UNIVERSITY DIGITAL LIBRARY AS A CENTER FOR INCREASING THE DIGITAL COMPETENCES OF STUDENTS
}

\author{
Tatiana Shopova \\ Department of Cultural Studies \\ South-West University "Neofit Rilski" \\ 66 Ivan Michailov str., Blagoevgrad, Bulgaria, 2700 \\ tansha@swu.bg
}

\begin{abstract}
This paper aims to outline the advantages of increasing the quality of education at the University by describing some important organizational approaches and methodological guidelines for the development of digital competences among students. The study focuses on the level of digital (library) competencies among students and their need to use scientific information sources in the University Library. A survey was conducted using the direct individual inquiry method through a pre-designed questionnaire comprising 20 questions. The statistical apparatus includes statistical methods - frequency, mean value and confidence level - $95 \%$. The survey results suggest that in today's digital society it is particularly important for the Library to become an information-communicative center for improving the students' skills by using the rich collection of information and digital resources and increasing the quality of education and training at the University. The presented study seeks to offer new approaches and ways to motivate students toward effective use of digital information and of new tools for working in the digital environment.
\end{abstract}

Keywords: digital literacy, university students, digital library, librarians, librarian guide, digital repository.

\section{Introduction}

The acquiring of skills to use the new tools for accessing knowledge and the broad development of digital literacy is increasingly becoming a condition for promoting the employability of every citizen in a world where digital technologies are beginning to determine people's way of life and thinking. It is no coincidence that in 2007 the European Commission has highlighted the need to consider the problem of digital literacy [1]. Focusing the efforts on the learning outcomes into the education process has shown the need to build universal skills and competencies that are crucial for individual development and competitiveness in the digital age. Among these new skills, special emphasis was placed on building critical thinking, initiative and teamwork that will prepare individuals for their careers. In this regard, the highlight was put on forming skills for management, interpretation, presentation, critical evaluation of information, capacity for its building or application in the digital environment [2]. The adopted by the European Commission strategy for creating a digital society and developing digital skills is a continuation of 
the efforts in the Member States' education policy for supporting the employment, growth and competitiveness [3].

In today's university education, the integration of information and communication technology in the processes of teaching and learning, requires students to adapt to the new literacy by developing thinking skills (such as problem solving, reasoning and critical assessment), research skills (such as gathering, evaluation and organization of information, argued writing, generating new ideas), cooperation and self-control skills. In the created Framework for information literacy for higher education, the Association of College and Research Libraries [4] draws attention to the role played by the IT ecosystem in the life and the work of people, as well as on the new responsibilities of students to find and use data and information in the creation of new knowledge in the information environment. The term "metaliteracy" has been introduced as a set of skills, where students are consumers and creators of information and can successfully collaborate in teams and communities. Moreover, what is required is the "behavioural, affective, cognitive, and metacognitive engagement with the information ecosystem" [4, Introduction section], which is crucial for lifelong learning.

The development of the digital competences among students and their preparation for creative, confident and critical use of information sources and resources is crucial to improving the efficiency of the learning process as well as adapting students to the ever-growing requirements of the global and dynamically developing labor market under "A Digital Agenda for Europe" initiative as a part of the Europe 2020 strategy [5]. Here too, the role of the University should be emphasized in the process of improving the information and communication skills of students in line with the European priorities in the field of digital technologies and future education.

Nowadays the library is increasingly becoming a center for gathering, storing, delivering and spreading human knowledge. It has become a Center for improving the digital competencies and skills of university students by offering a choice of appropriate ways and means for freely and quickly utilizing knowledge, accumulated in various scientific branches. By supporting and facilitating students in their scientific searches and finding knowledge, involved in the digital collections, the library develops students' abilities to creatively use them to generate new information.

It is well known that the modern library is characterized by flexibility, automatic adaptation, decentralization, by a wide variety of digital objects and collections, security of information, etc. It is not just a flow of data but an organized and managed collection of such in one or another area of human knowledge. It is particularly important in today's digital society that the University Library becomes an intermediary connection between "information and the user" and provides a rich set of digitized services that meet the users' expectations. In this way, it will support the process of student education and will help to achieve higher academic results.

Through the efforts to improve the digital skills and competencies of students, it will contribute for increasing their learning outcomes as they are no longer passive consumers of educational programs and services but active participants in the educational process. Their training and work skills related to the effective use of the digital resources and materials.

It is important to propose new practices and methodological guidelines to support and encourage students to improve their information literacy skills. This is related to the task of creating and using information learning resources, a database of scientific products of trainees and university lecturers with access to working with them to respond to the European Commission's new program adopted in 2016 for New Skills Agenda for Europe and the objective of modernizing education and training [3]. Among the priorities of the adopted Digital Education Action Plan are identified "better using of digital technology for teaching and learning" and "developing relevant digital competences and skills for the digital transformation" [6, p. 4]. The expansion of science communication through dialogue with the rich digital collections of libraries has become a real viable alternative for the academic community from the European universities. Digital libraries are rapidly developing and becoming the predominant way of gaining access to knowledge and training.

In the scientific literature the role of the library is increasingly focused with its rich information resources in the modern educational environment to support and facilitate the research ac- 
tivities of the students in building a strategy for information search, in acquiring criteria for finding and analyzing results, for selection and evaluation of electronic resources [7-9].

A significant place in this process is occupied by the library experts who can offer specific services for information literacy of students on the path of self-sufficing learning and "increasing the pedagogical communication between faculty and librarians fosters with a greater focus on learning outcomes and a shared understanding of information literacy as an institutional priority" $[10$, p. 636]. In some studies, the focus is on the possibilities of the library consultant to develop a critical capability by engaging students in questioning the power structures and relationships, involved in the production of information, especially within the academic environment [11].

In recent years, many studies, focused on the information skills of students to work effectively to meet their learning and research tasks, found the lack of developed skills in the use of the rich resources of the e-library [12-14]. Head and Eisenberg in their study established that almost all students turn to search engines — such as Google and Wikipedia, and increasingly trusted social networking sites to search for information to solve their tasks. Moreover, students relied on librarians less frequently and used them less often to prepare their course work $[12$, p. 8]. Smith et al. [14] in their study found that the students recognize the importance of information literacy skills, but are not aware of the library resources and services that can support and enhance these skills. According to the survey, the students need more guidance on how to "access, evaluate, and use information" [14, p. 90] as well as more awareness of library resources and services.

An interesting analysis of the results of a survey, conducted in 2016 among more than 300 students from the United States, Japan, Germany and Slovakia, found that $92 \%$ of respondents prefer paper to electronic information [15].

The Bulgarian polling agency Alpha Research showed in its study in 2014 that students in the University didn't use the library to its full potential. According to the data, only $3 \%$ of the respondents preferred using the library; $45 \%$ of them have chosen search engines on the Internet to search for information [16].

Moreover, many researchers indicate the bond which exists between library information skills of the students and the academic success and the need to improve the collaboration between lecturers and librarians [14, 17-20]. It is not by chance that the library specialists are called "heart of the university" [17, p. 83], without them the whole university life subsides. Librarians are increasingly concerned about setting up a program to gradually acquire information literacy skills at the university. In her study Bowless-Terry concludes that the existing correlation between upper-division library instruction and higher success in graduating students suggest that information literacy training by library after the first year is important [17, p. 89-90].

In a study, dedicated to e-learning in the higher education, [21] also was found out that the majority of students at the South-West University have difficulties developing effective strategies to search for information; they rely heavily on Google as a source of information on the Web and lack the necessary skills to take advantage of the electronic library at the university. Conclusions have been drawn on the need for researchers to focus on enhancing the role of the digital literacy in the university area and on encouraging and motivating students for a more efficient usage of the electronic information resources in the learning environment. It is important to identify the approaches to effectively support and stimulate students in order to develop and enrich the range of their skills in using the University Library's variety of information sources and digital resources. Attention was drawn to the need to enrich the library funds with access to world-class scientific quality resources established to enhance the quality of teaching and research work among students.

Gaps in the process of acquiring skills for information literacy were established in the next studies [22, 23], which concluded about the need to search for useful approaches and solutions to enhance the quality of education at the South-West University using the rich information resources of the University Library. Emphasis was placed on the need for enriching the library funds with access to well established international scientific quality resources for improving the quality of teaching and research among students. 
According to other Bulgarian authors [24], to meet the requirements of the academic and continuously expanding information environment, the library must become an active and productive participant in the process of building the university information system for management of learning.

\section{Aim of Research}

The current paper focuses on the level of information (library) literacy among the students at the South-West University - Blagoevgrad, their needs for using the sources of scientific information in the University Library (UL). It involves the main objectives and results of the survey (The survey was carried out by T. Shopova in collaboration with Nikolina Yaneva, library consultant at the South-West University Library) realized from the Center for New Media and Digital Culture in February-March 2016. The aim of the study was to understand:

1) the degree to which students use their information literacy skills in order to successfully perform their learning and research tasks;

2) the motivation of students to increase their information (library) skills;

3) how to help students to improve their information (library) literacy.

\section{Materials and Methods}

The methodology of the study corresponded to the intended objective and envisaged the conducting of a survey based on a questionnaire that had to establish:

1) the level of usage of the rich services and information resources of the University Library;

2) the level of knowledge and usage of means of access to information;

3) the extent of use of various library catalogues, funds and services;

4) the preferences of students to use certain types of library resources, services and facilities during their training;

5) whether the students use the information resources of an e- library and how often?

6) the degree of satisfaction of students by the university e-library in their scientific research and development;

7) the motivation of the students to raise their level of Information competence and outlining the approaches for its improvement in the university environment.

Questionnaire: The survey was conducted by the method of direct individual survey through a pre-designed questionnaire comprising 20 questions. The questionnaire was composed of three logical groups; the first three questions were introductory (age, specialty, internet use); the other two groups related to the use of the library with its rich resources and services in the learning process and the research, and establishing the motivation of students to enhance their library skills.

Sample size: The survey was conducted among 130 people - students and $\mathrm{PhD}$ candidates $(\mathrm{M}=50 ; \mathrm{SD}=24.62)$, who were randomly selected. $74.62 \%$ of the respondents were women and $25.38 \%$ were men of different courses and specialties at the South-West University. Surveyed students were studying mainly Social, Economic and Legal Sciences (43.85 \%), Humanities (23.85 \%), Natural Sciences, Mathematics and Informatics (10.77\%), Pedagogical Sciences (9.23\%), Health and Sports (3.85\%). $78.26 \%$ of the respondents were in the range of $18-23$ years old.

Data processing: The statistical apparatus includes statistical methods - frequency, mean value and confidence level - $95 \%$.

The following tentative assumptions were made in the survey:

1) most students at the South-West University do not benefit enough from the library information services and resources in the preparation of their teaching and research assignments;

2) most university students do not have the needed skills for using the rich variety of electronic resources and services at the university library. They prefer to use the Google search engine and its services as a primary source of information on the Web.

\section{Results}

According to the data obtained, the majority of respondents said they had daily access to the Web $-84.62 \%$, while those who answered "rarely" were $2.31 \%$. 
In Table 1 the study showed that most students, included in the sample, didn't effectively used the library and information services in the University. Only $29.23 \%$ answered "yes, often" and $40 \%$ - "sometimes".

Table 1

Frequency of using the library services at the University

\begin{tabular}{ccc}
\hline Do you use the library and information services at the University Library? & N & \% \\
\hline Yes, often & 38 & 29.23 \\
Sometimes & 52 & 40.00 \\
Rarely & 12 & 9.23 \\
Very rarely & 5 & 3.85 \\
No, but I think to inform myself & 7 & 5.38 \\
Mean & 22.8 & 17.54 \\
SD & 18.80 & 14.46
\end{tabular}

In Table 2 is presented how often the students use the e-library at their university. According to the data, prevailing was the number of students who very rarely $(42.31 \%)$ used the services of the e-library at the University in the process of their training. Few were the students who used the library every day (3.08 \%), or 2-3 times per week (19.23\%).

Table 2

Frequency of using the e-library services at the University

\begin{tabular}{ccc}
\hline How often do you use the e-library services? & N & \% \\
\hline Every day & 4 & 3.08 \\
$2-3$ times a week & 25 & 19.23 \\
$2-3$ times a month & 27 & 20.77 \\
Once a month & 19 & 14.62 \\
Very rarely & 55 & 42.31 \\
Mean & 26 & 20.0 \\
SD & 16.59 & 12.76
\end{tabular}

The survey showed in Table 3 that of the library information resources it was given preference to the printed books and magazines $-60 \%$. Fewer students used the resources of the e-library and sought electronic books and journals $(30.77 \%$ ) or digitized primary sources $(3.08 \%)$. Very few were students, who used archives (2.31) or consultations (6.15) in their research.

Table 3

Use of different types of library information resources

\begin{tabular}{ccc}
\hline What library information resources do you use in your research? & $\mathbf{N}$ & $\mathbf{\%}$ \\
\hline Electronic books and journals & 40 & 30.77 \\
Printed books and journals & 78 & 60.00 \\
Digitized primary sources (manuscripts and rare editions) & 4 & 3.08 \\
Archives & 3 & 2.31 \\
Research consultations & 8 & 6.15 \\
Other & 1 & 0.77 \\
Mean & 22.33 & 17.18 \\
SD & 28.23 & 21.71
\end{tabular}


Few were the students who took advantage of the interlibrary loan services or used the advice and assistance of a library specialist. The interlibrary loan services were used only by $5.38 \%$ of the surveyed students, $29.04 \%$ of them rarely and $33.85 \%$ has never used them. There were also not many students, who in the preparation of their academic and research tasks were consulting a librarian. As the data showed, $31.54 \%$ of the respondents choose to use often the advice and assistance of a library specialist, sometimes $-28.46 \%$ of them, rarely $-24.62 \%$ and never $-14.62 \%$.

In preparing their research tasks the majority of the respondents gave their preference to Google as a means of access to information (75.38\%) and to a much lesser degree to academic search engines such as Google Scholar (28.46 \%), to academic databases such as Science Direct, Springer Link, EBSCO Publishing and others (6.92\%) or to open electronic resources such as DOAJ (6.92 \%). It can describe the following linear equation $\mathrm{R}^{2}=1$ in Fig. 1.

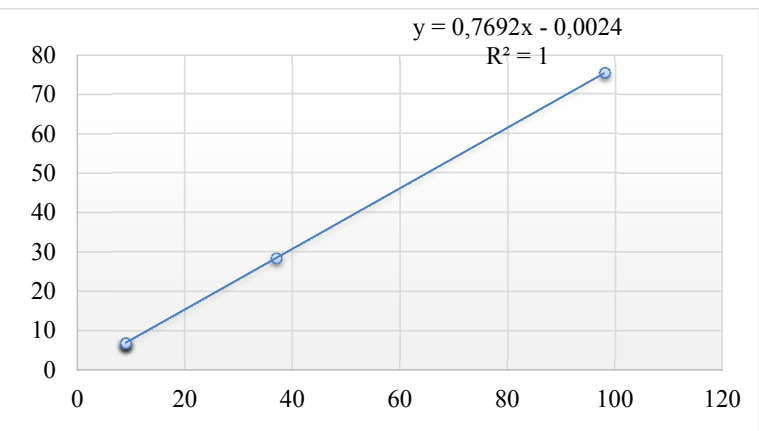

Fig. 1. Linear equation of using means of access to information

In Fig. 2 are presented the mean value, standard deviation and confidence level. MV was $29.4 \%$ at a frequency of 98 to 9 ; SD was $28 \%$, and CL-95 \% - 27.4\%.

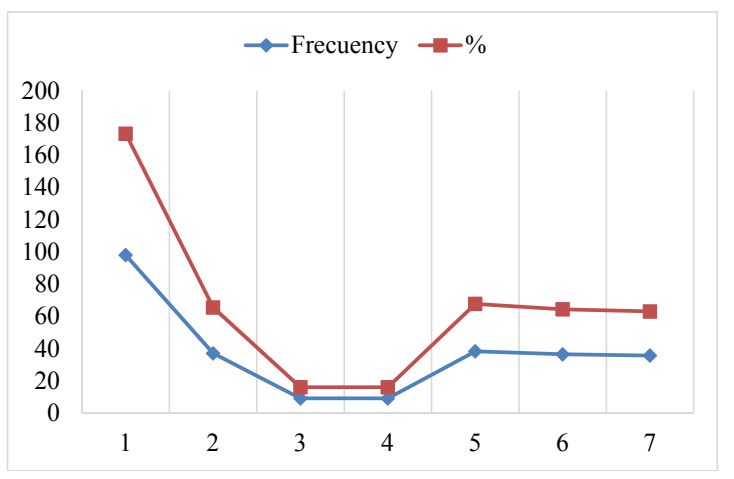

Fig. 2. Using means of access to information

The survey showed that the library catalogs as NALIS / National Academic Library-Information System/, WorldCat, etc. were used only by $3.08 \%$ and sometimes $-29.23 \%$.

It is presented in Table 4 that among the library collections and services, preference was given mainly to searching in online information systems (49.23\%) and $39.23 \%$ of the surveyed students consulted the help of the librarian in finding the necessary sources. Moreover, $44.62 \%$ said they took advantage of organized classes/lessons/ in information literacy while $49.23 \%$ answered "no".

In Table $\mathbf{5}$ is presented what types of library resources, services and tools the students use when they solve their scientific tasks. Most respondents indicated the traditional resources, such as books, records, etc. (47.69\%), and the electronic resources such as books, library catalogue, databases, digitized primary sources, etc. were preferred by $45.38 \%$ of the respondents. 
Table 4

Using library collections and services and seeking the assistance of a librarian (in \%)

\begin{tabular}{cccccc}
\hline Do you use library collections or services such as: & Yes, often & Sometimes & Rarely & Very rarely & No, never \\
\hline $\begin{array}{c}\text { Finding information on the book market and the range of } \\
\text { the information resources }\end{array}$ & 8.46 & 34.62 & 28.46 & 6.15 & 20.0 \\
$\quad$ Databases & 16.15 & 37.60 & 20.0 & 6.92 & 16.15 \\
$\quad$ New books in various fields of scientific knowledge & 13.08 & 34.62 & 26.92 & 8.46 & 15.38 \\
$\quad$ Searching in online information systems & 49.23 & 30.77 & 10.77 & 2.31 & 6.15 \\
Assistance of a librarian & 39.23 & 27.69 & 16.92 & 6.15 & 9.23 \\
Mean & 25.23 & 33.06 & 20.61 & 6.0 & 13.38 \\
SD & 16.02 & 3.45 & 6.51 & 2.03 & 5.0
\end{tabular}

Table 5

Using types of library resources, services and tools (in \%)

\begin{tabular}{|c|c|c|c|c|c|}
\hline Use of library resources, services and tools to research & Yes, often & Sometimes & Rarely & Very rarely & No, never \\
\hline $\begin{array}{c}\text { Electronic resources such as books, library catalogue, } \\
\text { databases, digitized primary sources, etc. }\end{array}$ & 45.38 & 32.31 & 14.62 & 1.54 & 4.62 \\
\hline Traditional resources such as books, archives, etc. & 47.69 & 32.31 & 11.54 & 1.54 & 5.38 \\
\hline $\begin{array}{l}\text { Services such as references, instructions, research consul- } \\
\text { tancy and interlibrary loan }\end{array}$ & 19.23 & 33.50 & 22.31 & 6.15 & 16.92 \\
\hline $\begin{array}{l}\text { Technical tools and equipment for individual and group } \\
\text { training, use of computers, photocopiers and printers }\end{array}$ & 50.0 & 23.85 & 10.77 & 3.08 & 10.0 \\
\hline Mean & 40.58 & 30.49 & 14.81 & 3.08 & 9.23 \\
\hline SD & 12.43 & 3.86 & 4.56 & 1.89 & 4.89 \\
\hline CL-95 \% & 12.18 & 3.79 & 4.47 & 1.84 & 4.80 \\
\hline
\end{tabular}

The survey data indicated that social media students prefer to rely more on Facebook (34.62 \%) and to a lesser extent on Academia.edu. (11.54\%) while $25.38 \%$ do not use these media sources when preparing their scientific tasks.

Another set of questions was related to the establishment of the degree of satisfaction of students by the e-library at the University that is presented in Table 6. The study found out that only $24.62 \%$ of the respondents believed that it fully meets their requirements, $25.38 \%$ had the opinion that it partially meets them for the purposes of their research.

It was interesting to understand the motivation of students to improve their information literacy skills. The data show in Table 7 that more than half of the surveyed students $(57.69 \%)$ understand that the work at the library impacts their academic success and therefore most of them would participate in short-term training seminars, tutorials, etc. in the library. According to the data obtained, $66.92 \%$ of the respondents said they were willing to participate in such courses to increase their library (information) skills and only $13.85 \%$ responded negatively. 
Table 6

Level of satisfaction of the electronic research library at the University

\begin{tabular}{ccc}
\hline To what extent the electronic research library satisfy your scientific research and developments? & $\mathbf{N}$ & $\mathbf{\%}$ \\
\hline It completely satisfies me & 32 & 24.62 \\
Partly for the purposes of my research work & 33 & 25.38 \\
More for education & 31 & 23.85 \\
I'm not satisfied & 3.31 & 29.31 \\
I can't decide & 25.60 & 19.69 \\
Mean & 11.38 & 8.75
\end{tabular}

Table 7

Motivation of students to improve their information literacy

\begin{tabular}{|c|c|c|}
\hline Does your work in the library improve your individual subject assessments? & $\mathbf{N}$ & $\%$ \\
\hline Yes & 75 & 57.69 \\
\hline Partly & 34 & 26.15 \\
\hline No & 8 & 6.15 \\
\hline I can' t decide & 11 & 8.46 \\
\hline $\begin{array}{c}\text { Would you like to participate in training courses organized in the university library to } \\
\text { increase your library (information) skills? }\end{array}$ & $\mathrm{N}$ & $\%$ \\
\hline Yes & 87 & 66.92 \\
\hline No & 18 & 13.85 \\
\hline I can't answer & 23 & 17.69 \\
\hline Mean & 42.67 & 32.82 \\
\hline SD & 31.41 & 24.16 \\
\hline CL-95 \% & 35.55 & 27.34 \\
\hline
\end{tabular}

The majority of the respondents also approved the introduction of digital collections of scientific works of students, undergraduates, graduate students and faculty in the University's library. Most said it was useful (58.46\%) or very useful (26.92\%) to be introduced and offered to use such resources. They were certain that using the digital collections would allow them to better prepare their theoretical works and have higher rating.

\section{Discussion}

The survey data showed that most students used both printed $(60 \%)$ and electronic library resources $(30.77 \%)$ in their scientific searches. This indicates a positive change in the attitude towards information resources compared to the studies in the previous years [22, 23]. Facilitated in 
their daily scientific searches of the electronic publication of information, students largely rely on the electronic format of searching books, newspapers, magazines, books, documents, etc. for the purposes of their learning. But they have not yet acquired skills to fully benefit from the advantages of the electronic library and its resources. Very few of them are familiar_with the research databases of the university's library and Google with its all services remains the preferred tool for accessing needed information.

The study confirmed the initial hypothesis about insufficient knowledge of information (library) literacy among the students, most of whom are not sufficiently aware of the abundance of electronic resources of the electronic university library; they still do not have the necessary skills and habits of using academic search engines and databases in their learning and research activities; the services of the e-library as a whole are rarely used.

Nowadays, the university libraries and their services are dominated by the information technology, which is used in all aspects of library activities to connect consumers with the information resources, including preparation of the data, discovery, delivery and storage of the recorded information [25]. The librarians began to play "a key role in the development of an integrated curriculum of information literacy" [26, p. 2] in today's learning environment. The role of the library consultant grows as long as he had to support students in searching, finding and evaluating relevant information.

With the exponential increase of information resources of major scientific and research libraries, students are faced with the problem of how selectively and efficiently to use these resources. Some library organizations and leading universities in the world have already developed programs and initiatives for building information literacy of students and carrying out the mission of universities [27-31]. The results of the study of Buchanan et al. [27, p. 105] show that based on the information in the curriculum of information literacy, the librarians have developed a plan to introduce library instruction at critical points in the courses to improve the learning process. Their work aims to develop the best combination of information resources and teaching methods for delivery of each course and assignment.

Training of students in the information literacy is offered by some libraries in Bulgaria. For example, the American University Library publishes on its website so-called guides on individual subjects and courses, in which the librarian has systematically prepared what the library has for each course and subject [32].

Martinova [33], basing on the European library practice, offers students and lecturers a Guide to the University Library at the Sofia University "St. Kliment Ohridski", as she manages to synthesize a variety of information.

The Library Information Centre at the University of Architecture, Civil Engineering and Geodesy in Sofia has developed a methodology for conducting the open library literacy course in order to be integrated into the curriculum of the first year students from all specialties. It has been also proposed a course of exercises on information literacy in the University for upperclassmen on a modular principle [34].

In the South-West University some steps have been made to assist students in finding scientific information in traditional and electronic format. But it is necessary to create a digital guide that would offer a list of links to the most frequently searched library resources in different branches of science and instructions for their finding (books, theses, journals, etc.), as well as wider information concerning how users can use the library services. The focus is on supporting e-learning in the University Library. There are now library lessons, which outline the required knowledge and skills that are learned when operating under internet environment for a broader study. Students learn about relevant websites that are useful for their scientific developments. Content analysis of the software is very important for the scope of qualitative scientific information as well as for online surveys. Based on their rich experience of knowledge and research, librarians are best placed in these electronic information resources and they are a key to the infinite form and type of information in the 21st century for university libraries. But this is not enough to organize on a modular basis all the content of a course in information literacy, which can be introduced in the library centre for training of students. 
The exhibited results of the current study show insufficient satisfaction of students with the electronic research library and their increased interest in the use of its digital resources. These results lead us to the conclusion that it is necessary to outline a new model for the university library that has developed physical resources and related services in digital format in support of teaching, learning and research [25, p. 164]. With the digitization of scientific products the university library can become a research centre that can assist in increasing the digital competence of the academic community. By offering a well-established and functioning digital scientific collection (from theses, dissertations, scientific research, etc.), it would provide readers with academic information from all the branches of science. The disclosure of certain scientific funds in the digital format is an important condition for improving the efficiency and effectiveness of the learning process as well as adapting students to the ever-increasing demands of the dynamically developing labour market. The precisely selected digital collection will support students and lecturers in their teaching and research activities, as well as keep track of the latest trends in specific areas of science.

The creation and sharing of information through the libraries' digital collections has become an attractive and truly feasible proposal for librarians and information professionals in many European universities. The digital libraries are increasingly evolving and becoming the predominant way of accessing knowledge and training. The very concept of a digital library directs to a system that provides access to digitized books and other textual documents. It covers a wide range of information objects, including primary objects, annotations and metadata.

By placing the foundations of institutional repository in the UL as a form of preservation and dissemination of scientific production in the digital format, students and teachers will be provided with quality library products. The introduction of the program guide will provide instructions to students and teachers on best practices related to the development of key competencies in the digital society.

The idea of the Repository is to maximize the results of the research by adding the scientific achievements of the South-West University in a digital storage that can be used online and will allow for data exchange with other university repositories. Internationally, it will not only provide the interaction between the consumers and the digital library using relevant digital library system, but also the interaction between the digital library systems and the exchange of metadata. It is envisaged that digital collections can be updated constantly and offer access to a wide variety of scientific products - theses, summaries of their theses and at later stages - books, articles, reports from scientific conferences, inventions, textbooks, multimedia presentations, images and other types of information.

Building institutional depository in the University Library will meet the priorities for the development of modern education, research and innovation, and will improve the role of the university as a tool for enhancing the academic and cultural internationalization of European higher education.

\section{Conclusions}

1. Outlining the importance of the problem concerning the analysing and evaluating the library information competencies among the students at the South-West University and the extent to which they are used, is an important prerequisite for building a more effective strategy for the University and to ensure a higher level of using digital technology as well as developing skills and competencies for effective inclusion of students in education and training.

2. In a practical sense, the presented study seeks to offer new approaches and ways to motivate students toward the effective use of digital information and of new tools for working in the digital environment - by creating programs for raising information literacy among the academic community and building a Digital Repository at the UL. The role of the Digital library is clearly outlined in the university environment for the collection, management and long-term storage of rich digital content, aiming to support the user communities and their ability to creatively use it to generate new information. It is increasingly being developed as a center for the development of key competences, including the role and place of the digital competence in the knowledge society. 
Creating and sharing information through libraries' digital collections has become an attractive and truly feasible proposal for librarians and information professionals in many universities in Europe. Digital libraries are increasingly evolving and become the predominant way of access to knowledge and training.

3. In the modern university environment, it is increasingly necessary to adopt appropriate approaches and measures to support and encourage students, especially those who are trained in the humanities and social sciences, to develop their literacy skills. This is related to the task of providing educational information resources, a database of the scientific output, created by students and lecturers in the university. And what is important to be emphasized here, this is the need for an adequate strategy to accelerate this process by modernizing the university library for students to develop and improve their academic skills and competences. In order to respond to the European priorities related to the use of digital technologies in the overall learning environment, it is necessary that the efforts of the university leadership, teachers and library staff focus on the provision of training programs on information (library) literacy and the building of a digital library with rich collections as a resource in the University Library. In the foreground, it is outlined the new role of the library specialists as "managers of information", who apart from the programs of information literacy they will offer, will also take on the function of establishing a system for organizing the knowledge at the University.

\section{References}

[1] Commission of the European Communities (2007). E-skills for the 21st century: fostering competitiveness, growth and jobs. European Commission, Brussels, 7.9. COM(2007) 496 fin.

[2] Katz, I. R., Macklin, A. S. (2007). Information and Communication Technology (ICT) Literacy: Integration and Assessment in Higher Education. Journal on Systemics, Cybernetics and Informatics (JSCI), 5 (4), 50-55. Available at: https://doaj.org/article/ce53793f73a340bc82f5d2962cc86454

[3] European commission (2016). A new skills agenda for Europe. Brussels, COM (2016) 381 final.

[4] ACRL (2016). Framework for information literacy for higher education, Adopted by the ACRL Board. Available at: http://www.ala.org/acrl/standards/ilframework 245 final $/ 2$

[5] European commission (2010). A Digital Agenda for Europe. Brussels, 26.8.2010. COM(2010)

[6] European commission (2018). Digital Education Action Plan, $\operatorname{COM}(2018) 22$ final.

[7] George, C., Bright, A., Hurlbert, T., Linke, E. C., Clair, G. St., Stein, J. (2006). Scholarly use of information: graduate students' information seeking behaviour. Information Research, 11 (4). Available at: http://InformationR.net/ir/11-4/paper272.html

[8] Lacović, D. (2014). Students' information behaviour and the role of academic library. Libellarium: journal for the research of writing, books, and cultural heritage institutions, 7 (1), 119-139. doi: http:// doi.org/10.15291/libellarium.v7i1.202

[9] Martin, J. (2008). The Information Seeking Behavior of Undergraduate Education Majors: Does Library Instruction Play a Role? Evidence Based Library and Information Practice, 3 (4), 4-17. doi: http://doi.org/10.18438/b8hk7x

[10] Booth, C., Lowe, M. S., Tagge, N., Stone, S. M. (2015). Degrees of Impact: Analyzing the Effects of Progressive Librarian Course Collaborations on Student Performance. College \& Research Libraries, 76 (5), 623-651. doi: http://doi.org/10.5860/crl.76.5.623

[11] Beilin, I. (2015). Beyond the threshold : Conformity, resistance and the ACRL Information Literacy Framework for Higher Education. In the Library with the Lead Pipe. Available at: http://www. inthelibrarywiththeleadpipe.org/author/ianbeilin?print=pdf-page

[12] Head, A. J., Eisenberg, M. B. (2010). Truth Be Told: How College Students Find and Use Information in the Digital Age, Project Information Literacy Progress Report. Available at: http://www. projectinfolit.org/uploads/2/7/5/4/27541717/pil_fall2010_survey_fullreport1.pdf

[13] Head, A. J., Eisenberg, M. B. (2011). How college students use the Web to conduct everyday life research. First Monday, 16 (4). doi: http://doi.org/10.5210/fm.v16i4.3484

[14] Smith, J. K., Given, L. M., Julien, H., Ouellette, D. DeLong, K. (2013). Information literacy proficiency: Assessing the gap in high school students' readiness for undergraduate academic work. Library \& Information Science Research, 35 (2), 88-96. doi: http://doi.org/10.1016/j.lisr.2012.12.001 
[15] Franklin, M. J. (2016). Sorry, technophiles: $92 \%$ of students prefer books to e-readers. Available at: http://mashable.com/2016/02/05/books-vs-e-readers/\#R8NwEG9X.5qL

[16] Alpha Research (2014). Survey of readers' practices in Bulgaria. Available at: https://www. abk.bg/page/practices2014

[17] Bowles-Terry, M. (2012). Library Instruction and Academic Success: A Mixed-Methods Assessment of a Library Instruction Program. Evidence Based Library and Information Practice, 7 (1), 82-95. doi: http://doi.org/10.18438/b8ps4d

[18] Mezick, E. M. (2007). Return on Investment: Libraries and Student Retention. The Journal of Academic Librarianship, 33 (5), 561-566. doi: http://doi.org/10.1016/j.acalib.2007.05.002

[19] Waldman, M. (2003). Freshmen's use of library electronic re-sources and self-efficacy. Information Research, 8 (2). Available at: http://www.informationr.net/ir/8-2/paper150.html

[20] Soria, K. M., Fransen, J., Nackerud, S. (2013). Library Use and Undergraduate Student Outcomes: New Evidence for Students' Retention and Academic Success. Portal: Libraries and the Academy, 13 (2), 147-164. doi: http://doi.org/10.1353/pla.2013.0010

[21] Shopova, T. (2011). E-Learning in Higher Educational Environment. Conference Proceedings „The Future of Education“. Florence. Available at: https://conference.pixel-online.net/conferences/ edu_future/common/download/Paper_pdf/ELE23-Shopova.pdf

[22] Shopova, T. (2013). Information and Digital Literacy - For a More Quality University Education. Scientific Bulletin - Education Sciences Series, 2, 130-151.

[23] Shopova T. (2014). Digital Literacy of Students and its Improvement at the University. Journal of Efficiency and Responsibility in Education and Science, 7 (2), 26-32. doi: http://doi.org/10.7160/ eriesj.2014.070201

[24] Milusheva, D., Martinova, G. (2005). E-Learning and the Place of the Academic Libraries. Bibliosphere, 6. Available at: http://eprints.rclis.org/24138/

[25] Raju, J. (2014). Knowledge and skills for the digital era academic library. The Journal of Academic Librarianship, 40 (2), 163-170. doi: http://doi.org/10.1016/j.acalib.2014.02.007

[26] Nwosu, M. C., Onwubiko, M. C. (2014). Information Literacy: A New Frontier of Learning for Librarians, Educators and Students in the 21st Century. Information and Knowledge Manage-ment, 4 (12).

[27] Buchanan, H., Webb, K. K., Houk, A. H., Tingelstad, C. (2015). Curriculum Mapping in Academic Libraries. New Review of Academic Librarianship, 21 (1), 94-111. doi: http://doi.org/10.1080/ 13614533.2014.1001413

[28] Knapp, A. J., Rowland, J. N., Charles, P. E. (2014). Retaining students by embedding librarians into undergraduate research experiences. Reference Services Review, 42 (1), 129-147. doi: http:// doi.org/10.1108/rsr-02-2013-0012

[29] Miller, K. E. (2014). Imagine! On the Future of Teaching and Learning and the Academic Research Library. Portal: Libraries and the Academy, 14 (3), 329-351. doi: http://doi.org/10.1353/ pla.2014.0018

[30] Moselen, C., Wang, L. (2014). Integrating Information Literacy into Academic Curricula: A Professional Development Programme for Librarians at the University of Auckland. The Journal of Academic Librarianship, 40 (2), 116-123. doi: http://doi.org/10.1016/j.acalib.2014.02.002

[31] Wetzel Wilkinson, C., Bruch, C. (2014). Building a Library Subculture to Sustain Information Literacy Practice with Second Order Change. Comminfolit, 8 (1), 82-95. doi: http://doi.org/10.15760/ comminfolit.2014.8.1.154

[32] American University in Bulgaria. Library Guides. http://aubg.libguides.com/index.php? $\mathrm{b}=\mathrm{g} \& \mathrm{~d}=\mathrm{a}$

[33] Martinova, G. (2001). Library guider like a part of information space, Bibliosphere, 1 (26). Available at: http://bibliosphere.eu/?page_id $=1252$

[34] Rafailova, P. (2009). The information literacy course - a part of the implementation of the European standards for university education. Annual of the University of Architecture. Civil Engineering and Geodesy, XLIII. 